Teologia i Moralność, Volumen 15(2020), numer 1(27)

doi: 10.14746/tim.2020.27.1.14

ORCID: 0000-0001-8807-882X

\author{
ELŻBIETA KOTKOWSKA \\ Adam Mickiewicz University in Poznań \\ Faculty of Theology
}

\title{
The concept of collective hope according to Józef Kozielecki and Chantal Delsol ${ }^{1}$
}

\section{Introduction}

The role of Christians in society in terms of hope is associated with two major orientations. In the first area, Christians should constantly contest the current state of a given society, and in the second one, constantly show the path of creative invention for it. Christians are convinced of the permanently existing, dialogical tension between now and not yet. They are convinced that, thanks to God, the future can be expected with hope, but because of human structural and personal sins, full perfection is not fully attainable in earthly life. For this reason, Christianity rationally argues that all people are responsible for the earthly shape of mutual relations and that achieving utopias in social relations is impossible.

Over the centuries, many works have been written on the subject of individual hope. Hope was considered in the psychological, philosophical, theological and biblical aspect. There are less elaborations devoted to the social dimension of hope, collective hope, which is not a simple sum of individual hopes, and at the same time is inseparably connected with it and shapes human beliefs. Regarding the existential attitude of a man living in hope, Arnobius the Elder (Arnobius of Sicca, $\sim \uparrow 330$ ) gave convincing arguments to include hope in making decisions. He argued that out of two expectations about the future which are impossible to be fully proved, the one which gives more hope should be chosen. Because the future, by its very nature, is uncertain

\footnotetext{
${ }^{1}$ Finansowane $\mathrm{z}$ funduszu Wydziału Teologicznego Uniwersytetu im. Adama Mickiewicza.
} 
and cannot be grasped, such behaviour is perfectly rational (Arnobius 2012, b. 2 sec. $4,18-21)^{2}$. The principle of Arnobius is applied by people who live with both individual and collective hope, defining their near and distant goals, as well as eschatological goals. Every person in their faith also needs justifications that science can give them ${ }^{3}$. An intellectual effort is needed, giving arguments to convince the reluctant [Titus 1,9$]$ so that to justify this hope in which, as Christians, we trust [1 Peter 3:15] (Kotkowska 2015, $195 \mathrm{ff})^{4}$. Both Józef Kozielecki (Kozielecki 1981; 2004; 2006; 2007) ${ }^{5}$, a Polish psychologist, and Chantal Delsol (Delsol 2006; 2010; 2015), a French philosopher, oppose the ideologization of social life as proposed by Francis Fukuyama (Fukuyama 2012), Richard Rorty (Stanford Encyclopedia of Philosophy 2020b) or Jacques Derrida (Stanford Encyclopedia of Philosophy 2020a), depriving people of hope for achieving far-reaching goals (Berger, Zijderveld 2010, 1-24).

\section{A society of hope}

Józef Kozielecki, a psychologist, clearly states that empirical results unambiguously confirm that hope without exceptions has a positive effect on overcoming the difficulties in achieving goals. He adds that the cases of the relations between the hypothesis and empirical research are rather rare (Kozielecki 2006, $76 \mathrm{ff})^{6}$. Psychology explores the role of hope in the actions of the individual and the small groups in which the individual is anchored. In

\footnotetext{
${ }^{2}$ Vide: "Since, then, the nature of the future is such that it cannot be grasped and comprehended by any anticipation, is it not more rational, of two things uncertain and hanging in doubtful suspense, rather to believe that which carries with it some hopes, than that which brings none at all? For in the one case there is no danger, if that which is said to be at hand should prove vain and groundless; in the other there is the greatest loss, even the loss of salvation, if, when the time has come, it be shown that there was nothing false in what was declared."

${ }^{3}$ From the very first centuries, Christian apologists knew that the truth of faith would not defend itself alone, it would take comprehensive effort, also the intellectual, to defend it.

${ }^{4}$ The first Christians lived at a time when many slanders were spoken about them in official circulation. The persecution had social acceptance. Only in the third century, thanks to the persistent work of apologists and testimonies of social assistance given by Christians, persecution ceased to be socially accepted. In the time of Diocletian, these were state actions and activities in the name of defending the cult of Roma and Augustus.

${ }^{5}$ The creator of psychotransgression, dealing with transgressive psychology, thinking psychology. He was interested in the principles that govern human communities. He justified the need for the so-called voice of reason, hence his work on the rationalization of recognized worldviews that give the power of persuasion.

${ }^{6}$ Józef Kozielecki strongly states, In psychological research it is very rare that empirical results confirm the hypotheses so clearly, most often reality allows exceptions, requires correction of assumptions, and even forces to modify initial assumptions.
} 
contrast, sociology or political science attempt to study the phenomenon of collective hope. The Polish psychologist proceeds from Kant's question: what may I hope? (Kant 1998, A 805/ B 833) to the question: what may we hope? He emphasizes that a seemingly small linguistic change has a major impact on the course of considerations (Kozielecki 2006, 192). Also William F. Lynch in his book Images of Hope argues that hope cannot be achieved and lived on solitary. His research concerned small groups, but this can be transferred to a wider research area (Lynch 2011).

Society is a great system that lasts for generations. There is a network of relationships in it, organized as individuals and groups. These groups are private institutions, enterprises, schools, banks, churches, hospitals, government offices, associations, parties, religious communities and associations. In such a society, the accumulated knowledge, not only scientific, but also relationships and impacts shaping the goals of a given society, play an extraordinary role. The organizers of social life, as Józef Kozielecki argues, operate in three basic areas such as culture, politics and economy (Kozielecki 2006, 193). As a psychologist, the Polish scientist adopts the research hypothesis assuming that in the organization of these social groups, hope and the opposing fear or anxiety are important factors. Both fear and hope concern the individual, but it is individuals that form social groups. Hope and fear / anxiety regulate the life of an individual and the life of the mentioned social groups to the same extent by influencing accepted beliefs (Kozielecki 2006, 194). In his concept of the society of hope, Józef Kozielecki categorizes them depending on the level of intensity of the two factors: fear and hope. He distinguishes three categories, societies in which fear prevails over hope, societies in which there is relative balance, and societies in which hope dominates over human anxiety and emerging fears. In the first category, wherever politicians or other authorities recognize the educational and omnipotent role of punishment, fear outweighs hope. This phenomenon is present not only in totalitarian states, but also in modern democracies. The stimuli in such societies have become soft and enlightened over time, that is, through mental interactions, they create pressure on specific individuals or social groups to change their beliefs towards the imposed goals. Ridiculing, depreciating or discrediting authorities is of great importance in spreading fears, dread, and creating an atmosphere of anxiety. In the second type of society, there is a relative balance that can be described as the carrot and stick approach. People having power and means of persuasion use punitive as well as positive stimuli. The third category is a society of hope, in which both individual and collective hope are the dominant factors. In such social groups, the majority of actions are aimed at rationalizing the foundations of human beliefs through qualifications, educational influence on life experience and emotions [cf. Fig. 1]. 


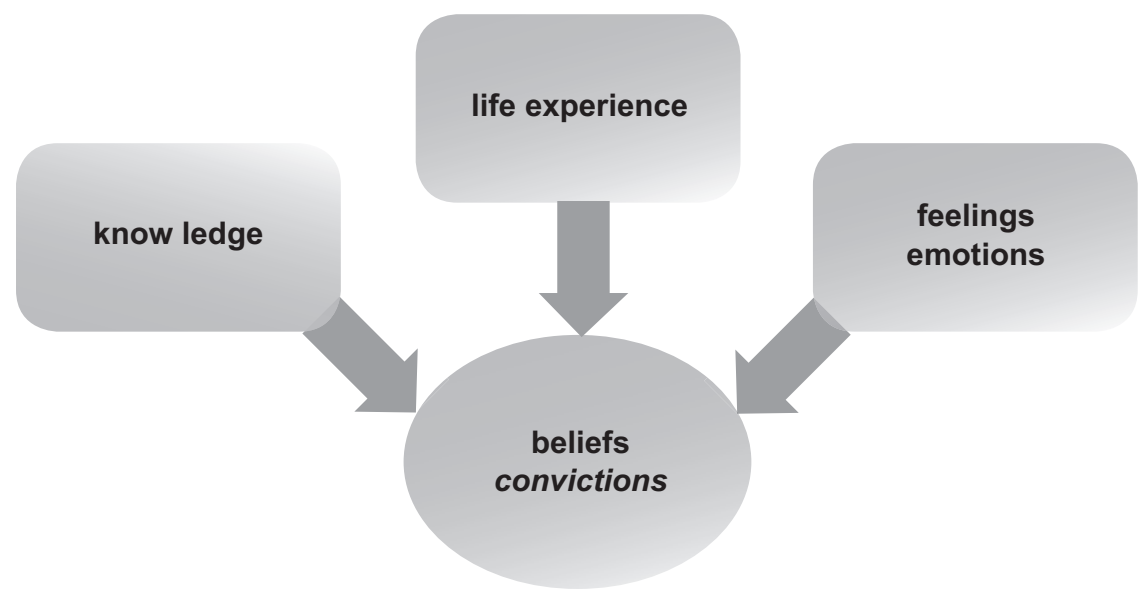

Fig. 1. Areas shaping human beliefs and convictions

Trends promoted in a society of hope convince that the set goals based on the common good are likely to be achieved. Józef Kozielecki concludes: it "can be said that collective hope is a group conviction that due to solidarity in carrying out tasks and thanks to strong motivation, a given community will in the future achieve a common good (goal) with a certain probability" (Kozielcki 2006, 197) ${ }^{7}$. This is not an unattainable vision or utopia because it takes into account human imperfection and it is expected to achieve the goals with some probability. Lack of fear-inducing actions is a critical frontier against the dictatorship of utopia, which Chantal Delsol analysed. In such societies, the means of persuasion are based on showing the attraction which is the truth and its values, for which it is even worth paying the highest price, even the ultimate of life (Kozielcki 2006, 194-195) ${ }^{8}$, and this is not nationalism or other fundamentalism.

\section{Chantal Delsol's diagnosis of society of late modernity}

At present times it is even more difficult to create a society of hope because, as Chantal Delsol argues, Europe in the 20th and 21st centuries is strugsearch.

${ }^{7}$ This level of hope is subject to psychological and sociological quantitative or qualitative re-

${ }^{8}$ Józef Kozielecki realizes that there is no state that meets these conditions, but he is convinced that there are such social life formations as foundations, cultural, political and economic institutions in which hope prevails over fear. 
gling with the trauma of the tragic past that results in its shame for cruel totalitarianisms. They were introduced in the name of the cult of the future and the creation of an ideal society, but they destroyed physically and mentally the entire groups of population ${ }^{9}$. According to the philosopher, former creators of utopian systems leading to terror and their successors did not get off the battlefield, still fighting for power over people and social groups. They still want to improve the human race according to their own visions, they want earthly salvation, but, out of necessity, they have moved to the positions of those who must give credibility to their ideologies. They no longer use physical terror, but ridiculing and undermining authorities, they promote ideologised scientific research, use propaganda and manipulation. In these actions, they create an atmosphere of fear of those who do not share their views by accusing them of all kinds of -isms like fundamentalism, nationalism, totalitarianism, etc. What they fear the most is paradoxically all changes, especially long-range changes, as well as distal and eschatological goals. They proclaim that the desire to achieve such goals gives rise to fundamentalism, which in turn raises terrorism. They particularly oppose references to eschatological horizons in Judaic and Christian religions. They judge their arguments in temporality, because the societies of Euro-Atlantic culture have created the so-called free prosperity that they want to maintain. The Demiurges of such social order know that utopia cannot be created here on earth, so they are of the opinion that one cannot hope for a better tomorrow, it is better to take pot luck. Chantal Delsol argues that the current situation is extremely difficult, because the man of late modernity in his beliefs escapes the relation to the truth, being supported in this regard by the media associated with leftist and liberal currents, and former creators of utopia. A man under the influence of currents of late modernity seizes the day, he does not want to have doubts, because they trigger a state of instability in them and are a source of anxieties that lead to nothing, as evidenced by the history of the 20th century. Lack of hope based on truth limits the possibility of trusting someone individually or institutionally, limits the possibility to sacrifice themselves for someone or something. One should live for the moment and every sacrifice of life for something more is nationalism or fundamentalism, which must be fought by all means. According to them, such extreme attitudes lead to terror. The argument circle closes with a conviction: we do not want any change, so we do not create distant goals, we want peace, so we cannot sacrifice our own lives to eschatological fantasies. If someone requires this from us, they are nationalists who must be avoided. Only then can we hope to maintain our "status quo". The Demiurges of social

\footnotetext{
${ }^{9}$ This cult prevailed during the Enlightenment period and, despite overcoming totalitarianisms, is still present in hidden form in attempts to create earthly perfection.
} 
life proclaim the hope of the moment, of pure temporality. In this way they convince that $a \mathrm{New}$ wonderful world in which one lives in a prolonged moment is created. They proclaim hope without a vision of the future, which condemns a man of late modernity to boredom or envy that others have used the moment more. New stoicism is being proclaimed as an answer to emerging anxieties. The creators of the new life support their beliefs only by what the sciences give, which do not reach into questions about the essence of being, but give the terror of so-called scientificity. These are deliberate actions, because you have to reject all valuations and there is no ethics or morality in science, there are facts. Therefore, man must escape / depart from eschatological hope, flatten his transgressions (Kozielecki, 2007) and desire for transcendence, limit his pursuit of distant, especially eschatological goals. The preacher of the new order became a man of literal temporality, escaping from the Christian and Judaic vision of the world, because religion requires too much. Human anxieties and questions, however, break through, despite many efforts to make the ethical side of deeds and morality in social relations in the name of science and progress known. In this regard, the Demiurges of social life give social groups a prosthesis of good actions dressed in the fight for human rights. Chantal Delsol reveals a basic contradiction and argues that claiming rights in the name of an indefinite dignity on the one hand is a violent reaction to earlier totalitarianisms, and on the other in the name of human protection, this ideology deprives him of roots, history, tradition and pride in national traditions. The philosopher states: "A new nihilism is introduced into societies given over to fear of certitudes" (Delsol 2006, 156).

If we take into account the words of John Paul II reminding us that man cannot be fully understood without Christ [1 Jn 4:9; Eph 1,4 n; Rom 8:29], it becomes clear that former utopians have stripped their ideologies of their ontic, ethical and religious roots. In a special way, the builders of a better tomorrow propagate an idealized, unreal concept of man. In their views there is a tone of conviction that one cannot speak of structural responsibility for evil, man is good, there is no primary evil in him, no shadow trail that prevents the creation of ideal structures here and now. There is always someone, some group or ideology responsible for the fact that the creators of the new order did not succeed. For this reason, they narrow the field of view of the future to the present, depreciate the eschatological horizon as well as the roots showing the source of evil. With persistence worthy of a better cause, they rebel against everything that has even a small connection with the world of values religion, especially the Christian one. Chantal Delsol even puts the words in their mouths: "We do not love life. We Love only our revolt" (Delsol 2006, 44). It is a rebellion against everything, which gives rise to the magnitude of the Euro-Atlantic culture. Rebellion against the philosophy of being, ethics, 
Christian morality, and historico-redemptive God's protection, who has specific requirements for man and his social relations. It is a rebellion in the name of human dignity, which ultimately depreciates this dignity and reduces it to being treated like an object. Modern man is subjected to activities that really hinder the creation of a society of hope. Relationships are already weakened in small social groups, which leads to loneliness, and as William F. Lynch writes, hope does not like loneliness (Lynch 2011). The situation is extremely difficult because, as we have shown above, the man of late modernity in his beliefs runs away from the relation to the truth, supported in this respect by the media associated with leftist and liberal currents and new creators of social life rooted in former utopias.

\section{To the truth in hope}

Convictions and beliefs are strongly grounded in the human personality because: "It is an intellectual state of certainty as to the rightness or reality of the view on a particular object" (Kotkowska 2018, 21 and Szaciło 1967, 70). In order to change false perceptions of reality and influence the change of beliefs, one needs to lead a person out of wrong thinking towards the clarity what it is like. Such a person can further influence the beliefs of social groups. Due to the emotional relationship with the situation as it is, this strategy requires patience and resilience to failure. Individual effort and trust led by hope in relation to others are necessary. Despite human flaws and lack of perfection, building a society of hope is possible, and even more real, because the risk of partial or total failure is taken into account.

Collective hope is not a simple sum of individual hopes. Social groups are united by shared awareness taken from views, ideas, myths and even stereotypes. On this awareness are based the personal beliefs of individuals that shape their behaviors, views, and moral principles. In a given group, these systems of principles and knowledge are passed on in the process of upbringing, teaching, propaganda or persuasion ${ }^{10}$. Józef Kozielecki emphasizes that in the group it is the individual that hopes and that by focusing on the uncertain future he sets goals. However, it is in the group that further, bolder and distal goals are formulated. It is confirmed by human experience and research of scientists ${ }^{11}$ that the group as a whole has a greater knowledge, greater imagination, and greater creativity (Kozielecki 2006, 196). It also has greater financial resour-

\footnotetext{
${ }^{10}$ If this is to be a society of hope, there should not be a compulsion to convey them by arousing fear or anxiety.

${ }^{11}$ Particularly worth paying attention to in this respect is heuristics, which explores the principles of creative group action.
} 
ces, which cannot be overlooked. On the other hand, the group influences the beliefs of the individual and if it is a community of hope, it results in mutual strengthening and consolidation as well as the change of beliefs towards the goals set in the uncertain future. Team hope is an emergent effect of individual hopes, thanks to which it has a higher level of socialization. It allows you to have probable certainty in achieving socially set goals. Its fulfilment requires not only contacts on the social micro-scale, but also on the macro-scale, where organizations, enterprises, foundations, associations, religious communities and offices communicate on behalf of individuals. As argues, "abandonment of interinstitutional ties means a failure of collective hope" (Kozielecki 2006, 197). Hope lets you get away from the destructive social utopias, while its defeat takes the wind out of individual hope sails. Similarly, as Chantal Delsol states, if we hope for a certain future, we base it on double certainty. On the one hand, we accept human weakness and on the other, we trust in the promise related to our goal. Both certainties intertwine although they maintain hope to varying degrees. Humanity permeated by its primeval fall has the right to hope for an indeterminate future. One should not run away from far-reaching goals that authenticate the promise that cynicism and stagnation promoting weakness will not prevail (Delsol 2006, 201).

Józef Kozielecki and Chantal Delsol argue that the strategy of help (Delsol 1993), i.e. skilful shaping of beliefs towards life in hope, should take place in social areas including politics, culture, education and economic life. Only then will the hope of the time to come give a greater likelihood of achieving the intended goals, and its level will be able to become high. Implementation of social hope will allow those who lose it to change their beliefs and enter the space of social relations pursuing even a very distant goal. Parents and children, a politician and his party, an entrepreneur and his team will be more effective, based on individual and collective hope, they will be able to shape independent activity. Thanks to this, they will be able to look bolder into the future and formulate common goals. Having a specified distal goal it is easier to look for ways to achieve it through partial goals. It is easier to maintain perseverance and determination in a situation of failure that will surely occur at some stage.

Other strategies that do not take into account the role of individual and collective hope are also present in social life. Józef Kozielecki defines them as reactive strategy and impotence strategy. It seems that for a late modernity man deprived of hope they are attractive, although they lead to stagnation and disappearance of the spirit of service in politicians and social activists. A reactive strategy shaping on the basis of behaviorism resembles a fire brigade or an ambulance. Activists and politicians are unable to take creative action, because without hope their horizon must be close and it should be somewhat touchable. They care about maintaining the status quo and are ruled by fear of 
change that brings new and unknown. The same applies to the strategy of impotence. Burnout may occur in social groups. Their members, even when they undertake specific tasks, in the absence of hope and overcoming fear of defeat, withdraw and fall into passivity. Resignation seems to defend them against total defeat, but they remain somewhat halfway to their destination (Kozielcki 2006, 207-208) $)^{12}$.

The society of hope is an assemblage of people who are more positive, more humanized and thus social relations are healthier. There is no primacy of the individual over the community or the opposite. In a community shaped in such a way, the arguments of the mind and controlled heart reflexes will be on an equal footing (Kozielecki 2006, 201-202) because, as Chantal Delsol argues: That is, must love them [existence and those beings who exist] more than the products of our own minds (Delsol 2006, 202). This means that human life goals are set by something more than just experimental sciences and the rationale of human reasoning. This individual and collective hope is not fully cognizable at the level of positive sciences. It is a secret that can be lived on and learned as a secret. However, it is the basis of democratic systems that respect the dignity of an individual human and his need for far-reaching hope. Hence, Józef Kozielecki convinces to build a society of hope and Chantal Delsol concludes that, as a democratic one, such society needs a monotheistic religion with eschatological hope and a personified God (Delsol 2006, 165-166).

\section{Conclusions}

The research effect is a juxtaposition of the views of the Polish scientist regarding the collective hope, with the belief of Chantal Delsol that the hope related to the monotheistic religion is needed for people to be able to develop and achieve distal and eschatological goals. Józef Kozielecki tried to show us how to build societies in which hope dominates over human anxiety and emerging fears. Chantal Delsol have showed us the ontological sources of the real threats of society of hope. They both know that collective hope is a great necessity in the face of intellectual utopias that have no confirmation in scientific psychological and sociological research. These conclusions were developed in the area of psychology, sociology and philosophy and are the support for beliefs and convictions about the value of eschatological hope.

\footnotetext{
${ }^{12}$ These issues will not be discussed in more detail as going beyond the subject of this article.
} 


\title{
POJECCIE NADZIEI ZBIOROWEJ \\ JÓZEFA KOZIELECKIEGO I CHANTAL DELSOL
}

\begin{abstract}
Abstrakt
W niniejszym artykule ukażemy koncepcję nadziei zbiorowej polskiego psychologa Józefa Kozieleckiego. W obszarze psychologii i socjologii daje potwierdzone w tych naukach argumenty wskazujące na potrzebę uzasadnionej nadziei zarówno indywidualnej, jak i zbiorowej. Na tej bazie przekonuje do budowania społeczeństwa nadziei, gdzie góruje ona nad lękiem przed niedookreśloną przyszłością i wszelkimi zmianami. Wyraźnie stwierdza, że trzeba się przeciwstawić ideologizacji życia społecznego w stylu Francisa Fukuyamy, Richarda Rorty’ego czy Jacques'a Derridy. Tworzą oni intelektualne utopie, niemające potwierdzenia w naukowych badaniach psychologicznych i socjologicznych, choć są nośne w wielu kręgach kulturowych późnej nowoczesności. By wzmocnić to przekonanie Józefa Kozieleckiego, odwołamy się do badań Chantal Delsol francuskiej filozof politycznej. Badała ona zmiany kulturowe i polityczne w Europie w XX i XXI wieku. Ona określiła ten czas jako „późną nowoczesność”. W swoich pracach stawia uzasadnioną diagnozę, że pewne nurty niszczą nadzieję na osiąganie dalekosiężnych celów zarówno indywidualnych, jak i zbiorowych, a tym bardziej nadzieję eschatologiczną w imię tworzenia społecznych utopii. Efektem badawczym będzie zestawienie poglądów polskiego naukowca dotyczących nadziei zbiorowej z przekonaniem Chantal Delsol, że nadzieja, i to ta związana z religią monoteistyczną. jest ludziom potrzebna, by mogli się rozwijać i osiągać zarówno dystalne, jak i eschatologiczne cele. Wnioski zostały wypracowane w obszarze psychologii, socjologii i filozofii i wspierają przekonanie o wartości nadziei eschatologicznej.
\end{abstract}

Słowa kluczowe: przekonania; nadzieja; społeczeństwo nadziei; zbiorowa nadzieja; Józef Kozielecki; Chantal Delsol

Keywords: beliefs; convictions; hope; society of hope; collective hope; Kozielecki Józef; Delsol Chantal

\section{BIBLIOGRAPHY}

Arnobius (2012), The Sacred Writings of Arnobius. Adversus nationes, book 2, Altenmünster: Jazzybee Verlag.

Berger P., Zijderveld A. (2010), In Praise of Doubt. How to Have Convictions Without Becoming a Fanatic, New York.

Delsol Ch. (1993), Le principe de subsidiarité, Paris.

Delsol Ch. (2010), Qu'est-ce que l'homme? Cours familier d'anthropologie, Paris

Delsol Ch. (2006), The unlearned lessons of the twentieth century. An essay on late modernity, transl. by R. Dick, Wilmington. 
Delsol Ch. (2015), Unjust justice. Against the tyranny of international law, Wilmington.

Fukuyama F. (2012), The end of history and the last man, London.

Kant I. (1998), [online] 2013, Critique of Pure Reason, transl. by Paul Guyer, Edith Cambridge University Press, DOI: 10.1017/CBO9780511804649.

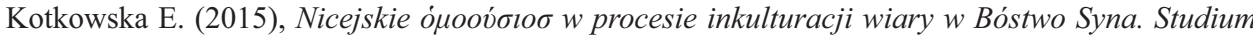

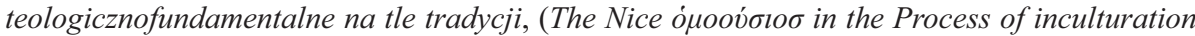
of the Faith in the Divinity of the Son. A Fundamental-Theological Study against the Backdrop of Tradition), Poznań.

Kotkowska E. (2018), Utrwalanie przekonań. Ujęcie teologicznofundamentalne i integralne, (Consolidation of Beliefs. a Theological Fundamental and Integral Approach), Poznań.

Kozielecki J. (1981), Psychological decision theory, Warsaw.

Kozielecki J. (2004), Spoleczeństwo transgresyjne. Szansa i ryzyko, (Transgressive society. Chance and Risk), Warszawa.

Kozielecki J. (2006), Psychologia nadziei, (Psychology of Hope), Warszawa.

Kozielecki J. (2007), Psychotransgresjonizm. Nowy kierunek psychologii (Psychotransgressionism. A New Direction in Psychology), Warszawa.

Lynch W.F. (2011), Images of Hope. Imagination as Healer of the Hopeless, Notre Dame, Indiana.

Stanford Encyclopedia of Philosophy (2020a), Jacques Derrida, https://plato.stanford.edu/entries/ derrida/ [dostęp: 27.06.2020].

Stanford Encyclopedia of Philosophy (2020b), Richard Rorty, https://plato.stanford.edu/entries/ rorty/ [dostęp: 27.06.2020].

Szaciło T. (1967), Przekonania (Convictions), Warszawa.

ElżBieta KotKowsKa - habilitated doctor of theological sciences. Professor at the Adam Mickiewicz University, the Department of Philosophy and Dialog of the Faculty of Theology. She is member of the European Society for Catholic Theology and the Association of the Fundamental Theologians in Poland. She undertakes organizational tasks and actions as member of Polish Accreditation Commission and the Council for the Quality of Teaching of Adam Mickiewicz University also as a member of Remote Teaching Council of Adam Mickiewicz University. Her scientific interests have recently focused on research into the possibilities of defining an integral method in fundamental theology and interdisciplinary studies of processes consolidating human beliefs, including religious ones. 